\title{
Upaya Preventif Perilaku Menyontek Siswa Melalui Layanan Dukungan Sistem
}

\author{
Muhyatun \\ Universitas Islam Negeri Sunan Kaljiga \\ muhyatun02@gmail.com
}

\begin{abstract}
The purpose of this study was to find out about the efforts made by teacher guidance and counseling at MTs. Roudlotul Banat Sidoarjo to prevent student cheating behavior. Based on the results of the teacher's guidance and counseling research at MTs. Roidlotul Bannat Sidoarjo has made several efforts that are expected to prevent students from cheating. By using system support in the form of information services and orientation guidance which is expected to provide understanding to students in cognitive, affective and psychomotor aspects regarding cheating behavior.
\end{abstract}

Keywords: Preventive Efforts, Cheating, System Support

Abstrak: Tujuan dari penelitian ini adalah untuk mengetahui tentang upaya-upaya yang dilakukan oleh guru BK di MTs. Roudlotul Banat Sidoarjo guna mencegah perilaku menyontek siswa. Berdasarkan hasil penelitian guru BK di MTs. Roidlotul Bannat Sidoarjo telah melakukan beberapa upaya yang diharapkan dapat mencegah kebiasaan siswa untuk menyontek. Dengan menggunakan dukungan sistem berupa layanan informasi serta bimbingan orientasi yang diharapkan dapat memberikan pemahaman kepada siswa dalam aspek kognitif, afektif dan psikomotorik mengenai perilaku menyontek.

Kata Kunci: Upaya Preventif, Menyontek, Dukungan Sistem

\section{Pendahuluan}

Perilaku menyontek adalah hal yang sangat sering dijumpai dalam kehidupan. tidak hanya di Indonesia fenomena-fenomena menyontek juga terjadi diberbagai belahan dunia lainnya. Salah satu fenomena menggemparkan dunia terjadi di tahun 2015 kemarin, tepatnya di India puluhan bapak atau wali siswa berkumpul dan memanjat jendela sekolah tepatnya dibelakang kelas anak mereka untuk memberikan bocoran lembar jawaban karena saat itu anaknya sedang menghadapi ujian sekolah, hal ini tentu tak luput dari pengawasan guru 
158 | Belajea: Jurnal Pendidikan Islam, Vol. 2, No. 02, 2019

saat itu, namun mereka kewalahan untuk menghentikan aksi bapak-bapak tersebut. $^{1}$

Selain itu disebutkan juga bahwa di Kazakhastan juga terdapat kejadian menyontek yang sangat mencengangkan, dimana seorang laki-laki menyamar menjadi perempuan dan masuk untuk menggantikan pacarnya yang pada saat itu seharusnya mengikuti ujian masuk perguruan tinggi. Kemudian di Indonesia sendiri menyontek seringkali dilakukan oleh siswa ketika menghadapi ujian kelulusan sekolah dan mirisnya terkadang hal ini juga di dukung oleh sistem lingkungannya termasuk lingkungan sekolah sendiri. Salah satu kasus kecurangan akademik yang terjadi di Indonesia adalah pada saat pelaksanaan UNBK dilansir dari laman berita online www.republika.com menyebutkan jika Kementerian Pendidikan dan Kebudayaan (Kemendikbud) melakukan pemeriksaan terhadap lima oknum guru yang diduga telah melakukan kecurangan selama penyelenggaraan ujian nasional berbasis komputer (UNBK) pada tahun 2017. Hal ini membuktikan bahwa sekalipun ujian dilaksanakan dengan penggunaan komputer tetasp saja tidak sepenuhnya dapat meminimalisir praktik ketidak jujuran dan menyontek pada UNBK. Sebenarnya harus dilakukan dengan jujur karena Jujur juga mempunyai arti keselarasan antara berita dengan fakta yang ada. Jadi, kalau suatu berita sesuai dengan keadaan yang ada maka dikatakan benar atau jujur, tetapi kalau tidak maka dikatakan dusta atau bohong. ${ }^{2}$

Dari pemaparan diatas dapat dipahami jika faktor penyebab terjadinya perilaku menyontek tidak hanya berasal dari motif individu siswa saja. Namun, keadaan dari sistem dimana siswa tersebut berada juga memberikan pengaruh. Menyontek tentu bukanlah perilaku yang baik, dan termasuk dalam kategori perilaku kecurangan akademik. Perilaku kecurangan akademik mencakup seluruh perilaku tidak jujur yang dilakukan oleh siswa untuk mendapatkan sesuatu yang bernilai lebih, dan hal itu dilakukan oleh siswa baik dengan sengaja atau tidak sengaja. ${ }^{3}$ Dalam penelitian yang dilakukan oleh Noviana Dewi \& Dhian Riskiana menunjukkan bahwa karakter tidak jujur dari siswa muncul karena terdapat bebereapa dorongan, diantaranya dari sistem dan tuntutan lingkungan sebanyak $37 \%$ kondisi terpaksa ketika ujian, 27\% takut dimarahi apabila tidak lulus ujian

1Puri Kurniasih dkk, "Infografis Alasan Menyontek Dan Tipe-Tipe Penyontek: Pandangan Etika Mengenai Perilaku Menyontek" dalam jurnal "Jurnal Desain Vol. 06, Issue. 02, Januari-April 2019”.

2Siswanto, Upaya Guru Pendidikan Agama Islam Dalam Menanamkan, https://ojs.unsiq.ac.id/index.php/paramurobi/article/view/531

${ }^{3}$ El Fathin Mufakkir, M., Agung Listiadi, "Pengaruh Faktor yang Terdapat dalam Dimensi Fraud Triangle Tentang Perilaku Kecurangan Akademik" dalam jurnal "Jurnal Pendidikan Akuntansi (JPAK), vol. 4, No. 3, 2016 
159 | M u h y a t u n : Upaya Preventif Perilaku Menyontek Siswa

atau mata pelajaran, $23 \%$ faktor dari guru pengawas dan teman, $7 \%$ ingin sempurna, $7 \%{ }^{4}$

Selain itu dari wawancara yang dilakukan oleh penulis kepada seorang guru BK di salah satu sekolah menengah atas (SMA) di Jombang menyebutkan, disekolah tersebut perilkau menyontek sudah sangat lumrah dilakukan siswa, dan ketika ditanya alasan mengapa siswa melakukan hal yang demikian? Mereka menjawab supaya mereka tidak remidi dan tidak dimarahi oleh orang tua, selain itu siswa juga menyebutkan jika mereka menyontek karena mereka kurang waktu belajar, padatnya aktivitas ketika mereka harus menyelesaikan tugas-tugas sekolah dan mondok secara bersamaan.

Dan orang tua mereka sendiri kadang tidak mengerti kendala yang dihadapi siswa, sehingga supaya tidak dimarahi dan mendapatkan hasil yang baik mereka memilih menyontek. Guru BK menjelaskan, seringkali anak-anak mengeluh, dan merasa stress dengan hal tersebut, selain itu karena disekolah tersebut dibawah naungan yayasan disediakan pula kelas Hafidr-Hafidzah, yang kemudian tidak sedikit pula orang tua juga meminta anaknya menghafal AlQuran dan masuk ke kelas Hafidr-Hafidzah. Tidak selesai dengan tuntutan di pondok, kewajiban menghafal, kemudian belum lagi tugas sekolah, ulangan harian, tidak sempat mempersiapkan diri akhirnya banyak siswa mau tidak mau melakukan kecurangan dengan menyontek dalam proses belajarnya disekolah.

Upaya yang dilakukan oleh guru BK sendiri sudah banyak, semisal memberikan nasihat dan peringatan jika menyontek adalah hal yang tidak benar. Namun, karena tidak semua dari guru dikelas mempunyai peraturan yang ketat serta pandangan yang sama tentang begitu tidak baiknya dampak dari perilaku menyontek, kebiasaan siswa meyontek belum dapat di reduksi dengan baik. Sikap kooperatif antara guru dan orang tua dalam membantu proses belajar siswa supaya berprestasi tanpa harus menyontek adalah kerjasama yang luar biasa. Guru BK dapat memberikan layanan konseling yang dapat membantu siswa dalam menghilangkan kebiasaan menyontek dan mencegah perilaku menyontek pada siswa-siswa, dengan cara berkolaborasi bersama orang tua untuk mengubah persepsinya, jika nilai bukanlah segalanya dan mulai mencoba untuk memahami taraf kemampuan anak disekolah.

Pada dasarnya setiap layanan yang ada dalam bimbingan konseling mempunyai berbagai fungsi menyebutkan salah satu fungsi layanan adalah fungsi

${ }^{4}$ Dewi, Noviana, Dhian Riskiana Putri "Peran Sistem Pendidikan Tinggi dalam Melunturkan Karakter Jujur Mahasiswa" dalam jurnal "Indigenous: Jurnal Ilmiah Psikologi vol. 3. No. 1. $2018 ”$. 
160 | Belajea: Jurnal Pendidikan Islam, Vol. 2, No. 02, 2019

preventif atau pencegahan timbulnya suatu masalah. ${ }^{5}$ Dan dalam fungsi pencegahan ini adalah pencegahan supaya siswa tidak melakukan kecurangan akademik berupa perilaku menyontek yang dapat mengganggu terhadap perkembangan belajarnya. Menurut pelaksanaan dari upaya preventif dapat berupa kegiatan-kegiatan seperti program orientasi, program bimbingan karir, inventarisasi data dan sebagainya. Layanan dukungan sistem merupakan komponen dari pelayanan dan kegiatan manajemen, tata kerja, infrastruktur dan pengembangan kemampuan profesional konselor atau guru bimbingan dan konseling, yang secara tidak langsung memberikan bantuan kepada peserta didik atau siswa untuk kelancaran perkembangan diri dan mendukung efektivitas dan efisiensi pelaksanaan layanan bimbingan dan konseling di sekolah. Oleh karena itu, tujuan dari penulisan artikel ini adalah untuk :

1. mengetahui bagaimana upaya preventif guru BK terhadap perilaku tidak jujur atau menyontek siswa serta

2. mengetahui desain layanan dukungan sistem di MTs. Roudlotul Banat Sidoarjo yang mendukung terhadap upaya preventif guru BK mengenai perilaku menyontek siswa.

Metode penelitian yang digunakan dalam penelitian ini adalah metode kualitatif deskriptif. Metode kualitatif dalam aplikasinya mempunyai tiga prinsip analisis data, menurut Samsudi dalam tulisannya menyarankan tiga prinsip yang digunakan dalam proses analisis data metode penelitian kualitatif, diantaranya: Pertama, prinsip analisis data naturalistic, yaitu analisis data yang mendasarkan pada situasi nyata yang berubah secara alamiah, bersifat terbuka dan didalamnya tidak mengandung rekayasa pengontrolan variable. Kedua, prinsip analisis induktif, yaitu prinsip analisis data yang mendasarkan pada prosedur berfikir induksi, dimensi, asli, dan berhubungan penting yang dapat diungkap melalui pertanyaan terbuka. Ketiga, analisis data berdasarkan prinsip holistic, yaitu analisis data dimana peneliti totalitas dalam memahami fenomena dan tidak melihat fenomena secara parsial. ${ }^{6}$

Berikutnya dengan berdasarkan saran prinsip analisis data kualitatif di atas, penulis dalam rangka memamparkan deskripsi data terkait dengan desain layanan dukungan sistem yang diberikan oleh guru BK dalam upaya preventif perilaku menyontek siswa di sekolah MTs. Roudlotul Banat Sidoarjo dengan akurat, mengacu kepada tiga prinsip tersebut, dengan pertimbangan sebagai berikut:

${ }^{5}$ Fatchurrahman, M., Bulkani, "Peran Guru Pembimbing Dalam Upaya Pencegahan Penyalahgunaan Narkotika Pada Siswa Sma Negeri Dan Swasta Kota Palangka Raya" Dalam Jurnal "Warta, Vol. 9, No. 1, Maret 2006: 21 - 27".

'Samsudi, "Desain Penelitian Pendidikan", Semarang : UNNES Press, 2009, 119. 
$161 \mid \mathrm{M}$ u h y a t u n : Upaya Preventif Perilaku Menyontek Siswa

1. Data-data yang dikumpulkan adalah data deskriptif dan berupa kata-kata dari subyek yang diwawancarai.

2. Penelitian ini bertujuan untuk memaparkan dan memberikan gambaran mengenai desain layanan yang diberikan oleh guru BK di MTs. Roudlotul Banat Sidoarjo sebagai upaya preventif perilaku menyontek siswa.

3. Penelitian ini murni dan tanpa rekayasa dalam upayanya untuk mengungkapkan fakta-fakta di lapangan.

Metode pengumpulan data yang digunakan dalam penelitian ini adalah metode wawancara, yang dilakukan secara langsung dan mendalam kepada guru BK sekolah di MTs. Roudlotul Banat Sidoarjo serta studi dokumentasi melalui website resmi MTs. Roudlotul Banat Sidoarjo.

\section{Hasil Dan Pembahasan}

MTs. Roudlotul Banat Sidoarjo merupakan salah satu sekolah berbasis islam serta dibawahi oleh salah satu yayasan yang ada di Sidoarjo. Di MTs. Roudlotul Banat Sidoarjo terdapat 1 orang guru Bimbingan Konseling yang aktif dalam memberikan bimbingan dan layanan konseling. Setiap layanan yang diberikan mempunyai fungsi sebagaimana seharusnya yaitu fungsi pemahaman, penyelesaian masalah, pemeliharaan, pengembangan, advokasi dan juga fungsi preventif atau pencegahan.

Fungsi preventif merupakan fungsi yang berkaitan dengan upaya yang dilakukan oleh konselor untuk mengantisipasi dan mencegah berbagai masalah yang mungkin terjadi dan dihadapi oleh siswa. ${ }^{7}$ Melalui fungsi ini, konselor dapat memberikan bimbingan kepada siswa tentang cara menghindarkan diri dari perbuatan atau kegiatan yang dapat membahayakan dan merugikan dirinya. Adapun implementasi atau layanan yang dapat digunakan fungsi preventif adalah layanan orientasi, bimbingan kelompok dan layanan informasi kepada para siswa dalam rangka mencegah terjadinya tingkah laku yang tidak diharapkan

Salah satu layanan preventif yang diberikan oleh konselor sekolah MTs. Roudlotul Banat Sidoarjo adalah layanan preventif perilaku menyontek. Guru BK memaparkan jika di sekolah masih terdapat beberapa siswa yang sering kedapatan melakukan perilaku kecurangan akademik menyontek. Menurut guru BK, perilaku menyontek yang dilakukan oleh siswa di MTs. Roudlotul Banat Sidoarjo adalah seperti saling salin-menyalin tugas dikelas, menggunakan catatan ketika ujian, berbagi jawaban ketika ujian atau bahkan terang-terang berdiskusi

\footnotetext{
${ }^{7}$ Kamaluddin, "Bimbingan Konseling Sekolah" dalam jurnal "Jurnal Penidikan dan Kebudayaan, vol. 17, No. 4, 2011).
} 
162 | Belajea: Jurnal Pendidikan Islam, Vol. 2, No. 02, 2019

dengan teman sebangkunya selagi mengerjakan soal waktu ujian atau kuis berlangsung dikelas. Mengenai faktor yang menjadi penyebab perilaku menyontek siswa di MTs. Roudlotul Banat Sidoarjo adalah karena kebanyakan dari siswa berusaha supaya tidak remedi dan mendapatkan nilai yang tinggi ketika ujian meskipun itu bukanlah hasil belajar yang dia lakukan.

Selaras dengan pengertian perilaku kecurangan akademik menyontek yang dipaparkan oleh Bower dalam Kiki Nurmayasari yang mendefinisikan bahawa cheating atau perilaku menyontek adalah "perbuatan yang dilakukan siswa dengan menggunakan cara-cara yang tidak sah untuk mencapai tujuan yang sah dan terhormat yaitu mendapatkan keberhasilan akademik dan untuk menghindari kegagalan akademik". Perilaku kecurangan akademik tentu dianggap sebagai suatu permasalahan yang meresahkan bagi guru BK, oleh karena itu guru BK telah berupaya dengan mewanti-wanti sebelumnya kepada siswa untuk tidak menyontek ketika ujian atau kuis dan mengerjakan sebisanya, semaksimal mungkin.

Selama ini, perlakuan yang diberikan oleh guru BK kepada siswa yang ketahuan menyontek adalah berupa teguran. Teguran diberikan oleh guru BK supaya siswa tidak mengulangi perbuatannya, selain teguran siswa juga diberikan point sesuai dengan buku panduan pelanggaran yang memang sudah berlaku disekolah. Berbeda dengan perlakuan bagi siswa yang sudah menyontek, guru BK juga memberikan layanan yang berupaya untuk mencegah siswa lainnya supaya tidak melakukan kecurangan akademik.

Upaya tersebut berupa pemberian informasi yang disosialisasikan oleh guru BK guna memahamkan kepada siswa jika perilaku menyontek bukanlah perilaku yang baik serta bagian dari akhlak yang tidak terpuji. Guru BK juga meminta keterlibatan dari setiap guru mata pelajaran supaya tidak membiarkan muridnya menyontek ketika ujian ataupun mengerjakan tugas di kelas, serta menegur siswa secara langsung atau personal jika siswa tersebut kedapatan mencontek, informasi lainnya mengenai dampak dari perilaku menyontek disampaikan oleh guru BK secara langsung kepada siswa ketika masa orientasi atau pengenalan siswa baru.

Tujuan khusus dari pemberian informasi perilaku menyontek yang dilakukan oleh guru BK, adalah karena menurutnya jika guru aktif memberikan pengetahuan dan pemahaman tentang apa yang seharusnya dilakukan siswa ketika proses belajar dan apa yang tidak. Selain melibatkan siswa langkah-

${ }^{8}$ Nurmayasari, K., \& Murusdi, H. (2015). "Hubungan Antara Berpikir Positif dan Berperilaku Menyontek Pada Siswa Kelas X SMK Koperasi Yogyakarta" dalam jurnal "Empatby, Jurnal Fakultas Psikologi, 3(1), 8-15”. 
163 | M u h y a t u n : Upaya Preventif Perilaku Menyontek Siswa

langkah pencegahan ini juga meminta bantuan pihak lainnya, diantaranya adalah orang atau wali siswa. Ketika agenda temu wali murid, guru BK mempunyai tugas untuk menyampaikan upaya pendampingan belajar yang baik kepada siswa yang dilakukan di rumah, termasuk salah satunya adalah pentingnya orang tua untuk tidak terlalu memaksa siswa dalam memenuhi harapan mereka mengenai prestasi dan nilai yang tinggi, konselor menekankan jika setiap anak mempunyai potensi masing-masing, cukup berikan dukungan dan semangat untuk belajar dengan benar dan baik., karena itu merupakan bentuk support system yang sangat membantu kepada siswa dalam proses belajarnya.

Selaras dengan apa yang disampaikan dalam teori belajar Bloom yang menyebutkan jika seorang siswa dapat menguasai tugas-tugas yang diberikan kepada mereka di sekolah, namun, juga perlu untuk memahami jika sebagian siswa atau anak memang berbeda dengan teman-temannya yang lain, dan membutuhkan perhatian lebih khusus untuk kelancaran proses belajarnya.' Pandangan Bloom proses belajar siswa adalah proses peningkatan taraf hidup sebagai pribadi dan anggota masyarakat lewat perubahan dalam segi kognitif, afektif dan psikomotorik. ${ }^{10}$ Sama halnya dengan upaya guru BK di MTs. Roidlotul Bannat Sidoarjo untuk memberikan pembelajaran pengertian dan pemahaman siswa mengenai perilaku menyontek jika dianalisiskan dengan teori Bloom, upaya pencegahan juga telah meliputi aspek kognitif, afektif dan psikomotorik. Kognitif dimana siswa diberikan layanan informasi tentang pengertian mencontek yang merupakan bagian dari akhlak tidak terpuji, serta aspek afektif melalui teguran-teguran yang diberikan guru secara langsung diharapkan dapat memberikan siswa perasaan takut dan jera untuk tidak lagi mencontek, serta psikomotorik dimana guru BK sendiri melakukan orientasi kepada siswa dan wali murid tentang perilaku menyontek dan dampaknya.

\section{Penutup}

Kesimpulan dari penelitian ini adalah guru BK di MTs. Roidlotul Bannat Sidoarjo telah melakukan beberapa upaya yang diharapkan dapat mencegah kebiasaan siswa untuk menyontek. Dengan menggunakan dukungan sistem berupa layanan informasi serta bimbingan orientasi yang diharapkan dapat memberikan pemahaman kepada siswa dalam aspek kognitif, afektif dan psikomotorik mengenai perilaku menyontek. Berikutnya dengan adanya

'Patmonodewo Sumiarti, "Pendidikan Anak Prasekolab", Jakarta: Pusat Perbukuan, Departemen Pendidikan dan Kebudayaan Bekerjasama dengan PT. Rineka Cipta 2003.

${ }^{10}$ Sain Hanafy, Muh., "Konsep Belajar dan Pembelajaran" dalam jurnal Lentera Pendidikan, 2017, vol. 17, No. 1, Juni 2014, 71. 
164 | Belajea: Jurnal Pendidikan Islam, Vol. 2, No. 02, 2019

penelitian ini peneliti mengharapkan supaya penelitian berikutnya sudah mengarah pada bagaimana mengembangkan desain layanan-layanan konseling, dengan tidak hanya bertumpu pada layanan dukungan sistem, supaya membantu untuk mereduksi kebiasaan perilaku menyontek siswa.

\section{Bibiografi}

Dewi, Noviana, Dhian Riskiana Putri "Peran Sistem Pendidikan Tinggi dalam Melunturkan Karakter Jujur Mahasiswa" dalam jurnal "Indigenous: Jurnal Ilmiah Psikologi vol. 3. No. 1. 2018”.

El Fathin Mufakkir, M., Agung Listiadi, "Pengaruh Faktor yang Terdapat dalam Dimensi Fraud Triangle Tentang Perilaku Kecurangan Akademik" dalam jurnal "Jurnal Pendidikan Akuntansi (JPAK), vol. 4, No. 3, 2016

Fatchurrahman, M., Bulkani, "Peran Guru Pembimbing Dalam Upaya Pencegahan Penyalahgunaan Narkotika Pada Siswa Sma Negeri Dan Swasta Kota Palangka Raya" Dalam Jurnal "Warta, Vol. 9, No. 1, Maret 2006: $21-27$ ".

Kamaluddin, "Bimbingan Konseling Sekolah" dalam jurnal "Jurnal Penidikan dan Kebudayaan, vol. 17, No. 4, 2011).

Lensaterkini.web.id.(2015). "Aksi Mencontek Pelajar Paling Parab”, diakses dalam http://www.lensaterkini.web.id/2015/10/5-aksi-mencontek-pelajarpaling-

parah.html

Nurmayasari, K., \& Murusdi, H. (2015). "Hubungan Antara Berpikir Positif dan Berperilaku Menyontek Pada Siswa Kelas X SMK Koperasi Yogyakarta” dalam jurnal "Empathy, Jurnal Fakultas Psikologi, 3(1), 8-15".

Patmonodewo Sumiarti, "Pendidikan Anak Prasekolab", Jakarta: Pusat Perbukuan, Departemen Pendidikan dan Kebudayaan Bekerjasama dengan PT. Rineka Cipta 2003.

Puri Kurniasih dkk, "Infografis Alasan Menyontek Dan Tipe-Tipe Penyontek: Pandangan Etika Mengenai Perilaku Menyontek" dalam jurnal "Jurnal Desain Vol. 06, Issue. 02, Januari-April 2019”.

Prasetyo Adi, Wawancara 14-Maret-2019.

Republika.co.id. (2018). "Tindakan Menyontek dan Pendidikan Karakter" diakses melalui https://www.republika.co.id/amp version/

Sain Hanafy, Muh., "Konsep Belajar dan Pembelajaran" dalam jurnal "Lentera Pendidikan, 2017, vol. 17, No. 1, Juni 2014”.

Samsudi, "Desain Penelitian Pendidikan", Semarang : UNNES Press, 2009.

Sukardi, Dewa Ketut., "Pengantar Pelaksanaan Program Bimbingan Dan Konseling Di Sekolab: Buku Panduan Untuk Guru Pembimbing/Konseling Di SLTP Atau Sekolah Menengah", Jakarta: Rineka Cipta, 2000.

https://ojs.unsiq.ac.id/index.php/paramurobi/article/view/531 